\title{
Population Strategy and Economic Development in Shantou
}

\author{
Tian Guang ${ }^{a}$, Camilla H. Wang ${ }^{b}$, Wan Yongan ${ }^{c}$, Liu Yu ${ }^{\text {d, }}$, Chi Qishui ${ }^{\mathrm{e}}$ \\ Shantou University, Guangdong Province, China \\ agtian@stu.edu.cn, ${ }^{\mathrm{b}} \mathrm{kk}$ _wh@yahoo.com, \\ c17yawan@stu.edu.cn, dyliu@stu.edu.cn, ${ }^{\mathrm{e}}$ qschi@stu.edu.cn
}

*Corresponding author

Keywords: Development, Population Scale, Population Quality, Special Economic Zone

\begin{abstract}
A city's population size and quality will affect its economic development level and pace of development, which has been demonstrated by both theoretical research and practical experience. After an evaluation of Shantou City's social economic development, it is found that the quality of the existing population and the size are unable to meet the needs of further social economic development. Therefore, to accelerate social economic development comprehensively in Shantou, a suitable population size and quality of the population must be reached, which is one of the key issues to be considered.
\end{abstract}

\section{Introduction}

Existing economic theory and empirical studies indicate that the social economic development level of a region is closely related to its population size and quality (Li et al. 2007; Mahesh, Canning, and Wilde 2016). Moderate population growth and therefore its augmentation by immigration will generate generally beneficial effects upon economic growth and the welfare of the existing population (Simon 1989). The GDP growth per head resulting from faster growth in the labor force is higher than that in the entire population as well as from increased savings and investment (Ahmed et al. 2014). Moreover, demand from an increasing urban population will help farmers with access to markets in towns and cities (Cleland and Machiyama 2016).

After conducting a comparative analysis of the population sizes and qualities of Shantou, Zhuhai, Xiamen and Shenzhen, it is easy to find that the population size and quality of Shantou could not meet its social economic development need, and in fact have become a key factor restricting Shantou's all-round social economic development. Therefore, relevant policy making bodies and theorists, in developing the future social economic development strategies for Shantou, must consider the match between the population size and quality and the social economic development level, and then conduct comprehensive analytical investigation to present specific and practical policy suggestions, and thus to accelerate the all-round development of the social economy for Shantou SEZ.

\section{Theoretical Thinking and Model of Population and Economic Development}

The theories on population and economic growth include the population and economy theory of Malthus, the Harrod-Domar economic growth model, the Solow economic growth model and the endogenous economic growth model. However, these three theories fail to effectively explain many practical issues. While the endogenous economic growth theory broadens the hypothesis of the Solow economic growth model, taking technological progress and population factors as endogenous variables and considering technological progress as the engine of economic growth, therefore, this theory is more applicable to the real economic growth environment and deserves detail description here. This theory aims at certain developed countries in the world, such as the United States, exploring why the economy could realize a growth rate of $2 \%$ in the $20^{\text {th }}$ century and analyzing the source of technological progress behind the economic growth. Its production function is as follows: $\mathrm{Y}=\mathrm{AF}(\mathrm{K}, \mathrm{L})$ 
Where: $\mathrm{A}$ is the given technological level. In the production function, the returns to scale of $\mathrm{K}$ and $\mathrm{L}$ are constant and putting the creativity $\mathrm{A}$ into production as a production factor results in increasing returns. That is to say, if only labor force and capital are considered in the production function, the returns to scale will not change; however, if technological progress is added, the output will certainly increase, i.e., $\mathrm{n}$ times of labor force, capital and creativity stock generate a output over $n$ times. To realize economic growth, new creativity must increase gradually. In case that the quantity of researchers fails to increase with the increasing of population, creativity will not increase either. Only more researchers can produce more ideas, facilitating the constant increase of output, in this case, the growth rate of creativity is obviously related to the growth rate of population. In the endogenous economic growth model, another important aspect is that human capital is deemed as a key factor in technological progress, more people means more creative ideas and higher output level. Hence, when including the variable of human capital, the economic growth can be calculated by the equation: $\triangle \mathrm{Y} / \mathrm{Y}=\mathrm{a} \triangle \mathrm{K} / \mathrm{K}+\beta \triangle \mathrm{L} / \mathrm{L}+\triangle \mathrm{A} / \mathrm{A}$

That is, output growth $=$ labor share $\times$ labor force growth + capital share $\times$ capital growth + technological progress, where a denotes the share of capital in the output, $\beta$ denote the share of labor in the output, $\triangle \mathrm{A} / \mathrm{A}$ denotes technological progress, and $\alpha+\beta=1$. The above equation shows that: the source of economic growth is the growth of production factors and technological progress (Lewis and Liang 1990).

\section{Population Restrictions on Shantou's Economic Development}

Figure 1 describes the GDP growth rates and annual permanent population increase rates of the four SEZs of Shantou, Xiamen, Shenzhen and Zhuhai. It demonstrates that 1) in most years, the GDP of Shantou increases/decreases as the increase/decrease of population; 2) generally, the population and GDP growth rates of Shantou are lower than those of other cities; and 3) the population increase of Shantou always stays at a relatively low and stable level. Currently, Shantou's low population growth rate matches its low economic growth rate; however, in the long run, when the GDP growth rate of Shantou reaches or even exceeds those of other SEZs, its population growth rate must increase correspondingly.

To catch up with the rapid economic growth of Shantou in the future, Shantou's population growth rate must reach and maintain a higher level. In the case of Guangzhou, the provincial capital of Guangdong, in recent years, the natural population growth rate fell between $2 \%$ and $4 \%$, while the population growth rate of immigrants was as high as $10 \%$. There are reasons behind the rapid immigration expansion of Guangzhou. Each economic boom was followed by the influx of a swarm of immigrants, which became a part of the population of the city. During economic development, Guangzhou's GDP always stayed in $12 \%-15 \%$, which brought in waves of immigrants. It is especially worth noting that in 2007, the permanent population of Guangzhou exceeded 10 million to 10.0458 million, and in the same year, its GPD jumped from RMB 606.8 billion to RMB 705.1billion year over year. The coming of many young adults guaranteed the sufficient labor supply of Guangzhou, which filled the labor gap caused by the accelerated aging of the local people. It is true that Guangzhou was forced to accept immigrants due to the requirements of economic development; however, the fact that we cannot deny is that immigrants have become an important force promoting the economic development of Guangzhou. 


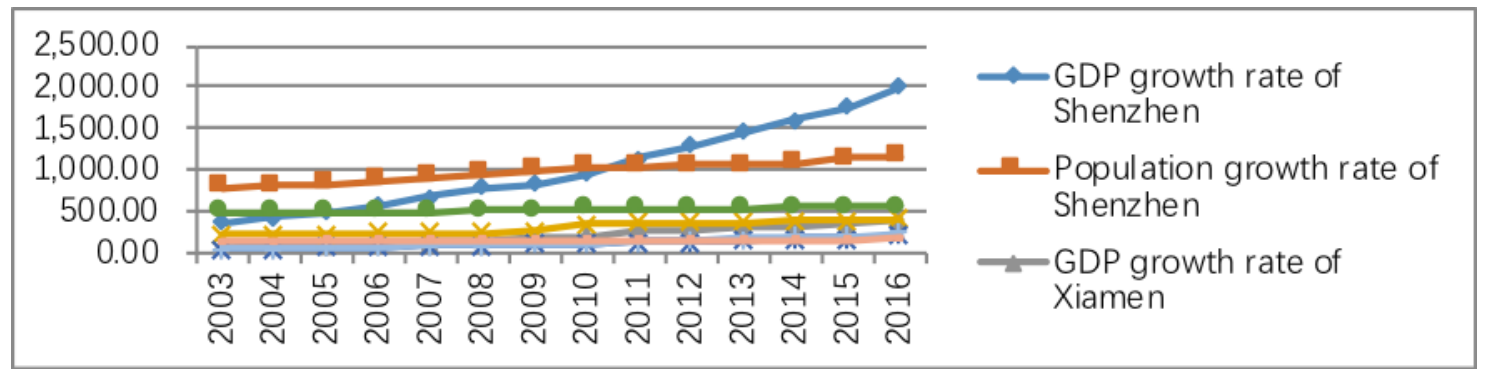

Fig. 1 Population and Economic Development Trends of the SEZs in China*

*Data sources: the statistical yearbooks of the SEZs, Beijing: National Bureau of Statistics of the People's Republic of China, 2016

Table 1. Educational Backgrounds of the Population in SEZs ${ }^{*}$

\begin{tabular}{|c|c|c|c|c|}
\hline & $\begin{array}{l}\text { People with the } \\
\text { background of } \\
\text { college and higher } \\
\text { education }\end{array}$ & $\begin{array}{l}\text { People with the } \\
\text { background of high } \\
\text { school and vocational } \\
\text { education }\end{array}$ & $\begin{array}{l}\text { People with the } \\
\text { background of college } \\
\text { and } \\
\text { higher } \\
\text { education } / 10,000\end{array}$ & $\begin{array}{l}\text { People with the } \\
\text { background of high } \\
\text { school and vocational } \\
\text { education/10,000 }\end{array}$ \\
\hline Shantou & 224461 & 783191 & 416 & 1453 \\
\hline Xiamen & 628560 & 667726 & 1780 & 1891 \\
\hline Shenzhen & 1779018 & 2482326 & 1718 & 2397 \\
\hline Zhuhai & 286911 & 383569 & 1839 & 2458 \\
\hline
\end{tabular}

*Data resources: the statistical bureaus of the SEZs, Beijing: National Bureau of Statistics of the People's Republic of China, 2016

The data of the 6th nationwide census in 2010 show that in the permanent population of Shantou, 224,461 people were with the associate degree or higher degree, and 783,191 people had received high school education (including vocational education), and if we divide the numbers by 10,000, we can get 416 and 1,453 respectively. In contrast, in Xiamen, the numbers were 628, 560 and 667,726, namely, 1,780 and 1,891 in every 10,000 people respectively; in Shenzhen, the numbers were $1,779,018$ and 2,482,326, or 1,718 and 2,397 in every 10,000 people respectively; in Zhuhai, the numbers were 286,911 and 383,569, or 1,839 and 2,458 in every 10,000 people respectively (for details please refer to table 1 ).

The contrastive analysis results of the above data indicate that Shantou falls far behind Xiamen, Shenzhen and Zhuhai in the higher education level, especially university education level of population, thus requiring a great increase of population quality. It is widely held that improvement of human capital, notably health and education, is the key to social and economic progress (Lutz, Butz, and KC 2014; Cuaresma, Lutz, and Sanderson 2014). In Shantou, there is only one comprehensive university-Shantou University, and according to its graduate employment statistics, most of the graduates chose to go to the Pearl Delta, and only less than $10 \%$ graduates stayed in Shantou. Besides, statistics show that the average years of schooling of the jobholders in Shantou are 9.12 years, lower than the average of 9.79 years in Guangdong, while in Shenzhen, Zhuhai and Xiamen, the numbers are 10.93, 10.96 and 11.1 years, respectively. As for the proportion of people with higher education background, the numbers for Xiamen, Shenzhen and Zhuhai are 21.1\%, $22.5 \%$ and $16.7 \%$ respectively, but only $9 \%$ for Shantou (for details please refer to table 2). 
Table 2. Educational Levels of the Jobholders in SEZs*

Average years of schooling

Proportion of people with higher education background

\begin{tabular}{lll}
\hline Shantou & 9.12 & $9.01 \%$ \\
Xiamen & 11.1 & $21.1 \%$ \\
Shenzhen & 10.93 & $22.5 \%$ \\
Zhuhai & 10.96 & $16.3 \%$ \\
\hline
\end{tabular}

*Data sources: the statistical bureaus of the SEZs, Beijing: National Bureau of Statistics of the People’s Republic of China, 2016

It is evident that Shantou is still far behind other SEZs in both population and labor quality. According to the endogenous growth theory model, namely, $\triangle Y / Y=\alpha \triangle K / K+\beta \triangle L / L+\triangle A / A$, if output increase $=$ labor share $\times$ labor growth + capital share $\times$ capital growth + technological progress, the increase of capital share $(\triangle K / K)$, labor share $(\triangle L / L)$ and technological progress $(\triangle$ A/A) can all lead to the increase of output growth rate $(\triangle \mathrm{Y} / \mathrm{Y})$. Therefore, to achieve a higher output growth rate $(\triangle Y / Y)$, Shantou needs to have faster increase in capital share $(\triangle K / K)$, labor share $(\triangle L / L)$ and technological progress $(\triangle A / A)$, while the rapid increase of labor share $(\triangle L / L)$ and technological progress $(\triangle \mathrm{A} / \mathrm{A})$ require the rapid increase of population size and quality, for they are supportive factors for the rapid development of Shantou in the future.

The rapid economic development of Shantou in the future requires a faster population growth; however, without the sufficient supplement of immigrants, the fertility rate of Shantou cannot support a rapid population growth. In this case, focus should be given to immigration policies, for injecting labor force into Shantou's rapid economic development. In terms of population quality, due to the lack of educational resources, the policies to attract and retain talents, and the attention to talents, the overall population quality of Shantou is relatively low compared with other developed areas, which restricts the powerful development of Shantou. Hence, measures shall be taken to increase the investment in educational resources, increase the attention of the government to talents, and develop various policies to attract and retain talents, thus improving the population quality of Shantou.

\section{Conclusions}

The economic development of a region is closely related to its population size and quality, and the speed of economic development needs the support of a certain population size. Among various production factors, labor is the most actively one which plays a key role in the social and economic development of the region. With the increase of the quality of labors, the innovation capacity and labor productivity of the region will go up, playing a significant role of constantly injecting vitality into the economic development of the region. Shantou is a SEZ, however, compared with other SEZs like Shenzhen, Zhuhai and Xiamen; it still falls far behind them in population size and quality. Therefore, to realize a rapid social economic development in the future, Shantou must take effective measures to increase its population size and quality greatly. In terms of the increase of population size, Shantou is required to make breakthroughs in labor immigration, business immigration and skilled immigration; while for the increase of population quality, Shantou should increase investment in education resources to create a good employment environment in which talents are respected and values and develop new payment and incentive systems which are attractive to talents. 


\section{Acknowledgements}

This study is supported by "Guangdong Planning Office Philosophy and Social Science, GD15XGL48”.

\section{References}

[1] Adam, S., Translated by Zhang Li. The Wealth of Nations, Nanjing: Yilin Press, 2012.

[2] Ahmed, S., Amer, Marcio, C., Go, D. S., Maliszewska, M., and Osorio-Rodarte, I., How significant is Africa's demographic dividend for its future growth and poverty reduction? Working Paper No. 7134, Washington DC: World Bank, Development Prospects Group, Policy Research, 2014.

[3] Ashraf, Q. H., Weil, D. N., and Wilde, J., The Effect of Fertility Reduction on Economic Growth, Population and Development Review, vol:39, pp. 97 - 130, 2013.

[4] Bell, M., Charles-Edwards, E., Ueffing, P., Stillwell, J., Kupiszewski, M., and Kupiszewska D., Internal Migration and Development: Comparing Migration Intensities Around the World, Population and Development Review, vol:41, pp. 33-58, 2015.

[5] Bernard, A., Bell, M., and Charles-Edwards, E., Life-course transitions and the age profile of internal migration, Population and Development Review, vol:40, pp. 213 - 239, 2014.

[6] Boserup, E., Population and Technological Change: A Study of Long-term Trends. Chicago, IL: University of Chicago Press Chicago, 1981.

[7] Cai, F., Wang, M., and Du, Y., Population Density and Regional Economic Development, Zhejiang Social Sciences, vol:6, pp. 12-16, 2001.

[8] Chen, S.Z., Ways for the Development of the Cultural Innovation Industry in Shantou, Journal of Shantou University (Humanistic and Social Science), vol:28, pp. 71-76, 2012.

[9] Cleland, J., and Manchiyama, K., The Challenges Posed by Demographic Change in subSaharan Africa: A Concise Overview, Population and Development Review, vol:43, 2016.

[10] Coleman, D., and Rowthorn, R., The Economic Effects of Immigration into the United Kingdom, Population and Development Review, vol:30, pp. 579 - 624, 2004.

[11] Cuaresma, J. C., Lutz, W., and Sanderson, W., Is the demographic dividend an education dividend? Demography, vol:51, pp. 299 - 315, 2014.

[12] Dyson, T. (ed.)., Population and Development: The Demographic Transition. New York, London: Zed Books, 2010.

[13] Fan, J.H, Chen, L., and Cai K.G., Some Strategic Thoughts on the Urban Development of Shantou: Based on the Positioning of Shantou, Jiangsu Commercial Forum, vol:7, pp. 141-142, 2007.

[14] Hanushek, E., Economic Growth in Developing Countries: The Role of Human Capital. Economics of Education Review, vol:37, pp. 204-212, 2013.

[15] Headey, D. D., and Hodge, A., The Effect of Population Growth on Economic Growth: A Meta-Regression Analysis of the Macroeconomic Literature, Population and development review, vol:35, pp. 221 - 248, 2009.

[16] Johnson, D. G., Population, Food and Knowledge, The American Economic Review, vol:90, pp. 1-14, 2000.

[17] Karra, M., Canning D., and Wilde, J., The effect of fertility decline on economic growth in Africa: A macrosimulation model, Population and Development Review, vol:43, 2016. 
[18] Keynes., The General Theory of Employment, Interest, and Money. Shanghai: Foreign Language Education Press, 2006.

[19] Lerch, M., The role of migration in the urban transition: A demonstration from Albania, Demography, vol:51, pp. 15 - 27, 2014.

[20] Lewis, and Liang X.M., The Theory of Economic Growth. Shanghai: Sanlian Bookstore, 1990.

[21] Li D.H., and Xia E.J., The Effects of Human Capital on China' s Economic Growth-A Study based on the Extended Solow Model, Chinese Journal of Population, Resources and Environment, vol:23, pp. 100-106, 2013.

[22] Li J.M., et al., The Relationship between China’s Population and Social Development: Status Quo, Trend and Problems, Population Research, vol:31, pp. 33-48, 2007.

[23] Li X., An Empirical Investigation on Issues Concerning the Economic Development of Shantou, Journal of Shantou University (Humanistic and Social Science), vol:20, pp. 17, 2004.

[24] Lutz, W., Butz, W.P, and Samir, K.C., World Population \& Human Capital in the Twenty first Century. Oxford, UK: Oxford University Press, 2014.

[25] Madsen, J. B., Ang, J. B. and Banerjee, R., Four Centuries of British Economic Growth: The Roles of Technology and Population, Journal of Economic Growth, vol:15, pp. 263-290, 2010.

[26] Marx K. and Engels F., Collected Works of Karl Marx and Frederick Engels. Beijing: People’s Publishing House, 1995.

[27] Sauvy, A., General Theory of Population. Beijing: Commercial Press, 1982.

[28] Schultz, T.W., Investment in Human Capital, The American Economic Review, vol:82, pp. 117, 1961.

[29] Simon, J. L., The Economic Consequences of Immigration. Cambridge, UK: Basil Blackwell, 1989.

[30] Skeldon, R., Migration and Development: A Global Perspective, International Migration Review, vol:33, 1997.

[31] Spaull, N., and Taylor, S., Access to what? Creating a composite measure of educational quantity and educational quality for 11 African countries, Comparative Education Review, vol:59, pp. 133 - 165, 2015.

[32] Tian, G., and Dai Q.Q., Administrative Resources and State Plan: Some New Strategic Thoughts on the Integrated Development of Chaozhou, Shantou and Jieyang, Journal of Southern Vocational Education, vol:3, pp. 53-61, 2013.

[33] Tian, G., Wang Y.F., and Dai Q.Q., Administrative Resources and State Plan: New Strategies for the Integrated Social and Economic Development of Greater Chaozhou-Shantou Region, Review of Economic Research, vol:59, pp. 69-71, 2013.

[34] Tian, G., National Population and Prosperity: Based on the Investigation of Jingyuan County, Journal of Ningxia University (Humanistic and Social Science), vol:3, pp. 60-62, 1983.

[35] Tian, X.Y. Of the Strategies for the Harmonious Population-Economic Development of the Third World, The Journal of World Economy, vol:8, pp. 27-32, 1989.

[36] Tian, G., Soft Power and Construction of Shantou Economic Special Zone: A New Breakthrough Point, Journal of Applied Business and Economics, vol:6, pp. 121-131, 2011.

[37] United Nations., Overcoming barriers: Human mobility and development, Human Development Report 2009. Basingstoke, UK: United Nations Development Program, 2009. 
[38] Xiao, L.J., and Zhang, J.L., The Relationship between China's Population and Social \& Economic Development in the Transformation Period. Chengdu: Southwestern University of Finance and Economics of Publishing House, 2005.

[39] Yang, Y.M., The Experience of Foreign Countries on Urban-Rural Integration and its Inspiration on the Urban-Rural Integration of Shantou, Journal of Xihua University (Philosophy and Social Science), vol:2, pp. 97-100, 2012.

[40] Zuo, X.J., The Effects of Population Increase on Economic Development, International Economic Review, vol:6, pp. 127-135, 2010. 